\title{
CORRESPONDENCE
}

\section{OCULAR SYMPTOMS IN GLANDULAR FEVER}

\section{To the Editorial Committee of the BrTtish Journal of OPHTHALMOLOGY}

SIRS-We are indebted to Dr. I. M. Librach for bringing to notice his two very interesting cases of glandular fever conjunctivitis (Brit. J. Ophthal., 1956, 40, 619), but his review of the literature is misleading. Dr. Librach asserts that there have been no reports of ocular manifestations of glandular fever in Great Britain since 1907 and that episcleritis has only been noted once before, and he implies that subconjunctival haemorrhages have not been previously described in this disease. He is surely mistaken about each of these three items.

The episcleritis, or circumscribed bulbar conjunctivitis, of glandular fever was vividly described by Chevallier and Bilski-Pasquier (1941). Subconjunctival haemorrhages were observed in glandular fever by Minot (1929 and 1936), and by Boger (1944), and they were recorded in Great Britain by Sears (1949). Tidy (1935), Stevenson and Brown (1943), and other authors have mentioned the not infrequent occurrence of conjunctivitis in glandular fever in Great Britian.

In 1955, in a discussion on lacrimal disease associated with infectious mononucleosis, I described an acute dacryo-adenitis in a Paul Bunnell-positive glandular fever which occurred in London. Some of the cases of dacryocystitis mentioned, but not described, were also true glandular fevers seen in London. The other cases in this report were seen in an epidemic of "Paul Bunnell-negative infectious mononucleosis" in Dunedin, New Zealand (Jones, Howie, and Wilson, 1952; Jones, 1954, 1955).

I should like to emphasize the distinction between the sporadic Paul Bunnell-positive cases seen in London and the negative epidemic cases seen in Dunedin (and similar cases seen in London), because it is likely that the latter group is due to a different aetiological agent or agents from the positive group. In other words, although similar, they are probably different diseases rather than differing reactions to the same disease, and it is therefore desirable (Leibowitz, 1953) to restrict the diagnosis of glandular fever to the Paul Bunnell-positive cases which give a characteristic absorption pattern of heterophil antibodies.

INSTITUTE OF OPHTHALMOLOGY, Yours faithfully, BARRIE R. JONES.

LONDON, W.C.1.

December 6, 1956.

\section{REFERENCES}

Boger, W. P. (1944). Sth. med. J. (Bgham, Ala.), 37, 546.

Chevallier, P., and Bilksi-Pasquier, G. (1941). Sang, 14, 546.

JoNes, B. R. (1954). Trans. ophthal. Soc. U.K., 74, 119. (1955). Ibid, , 75, 101.

Howie, J. B., and Wilson, R. P. (1952). Proc. Univ. Otago med. Sch., 30, 1.

LeIBOWITZ, S. (1953). "Infectious Mononucleosis," p. 112. Grune and Stratton, New York. LIBRACH, I. M. (1956). British Journal of Ophthalmology, 40, 619.

Minot, G. R. (1929). Med. Clin. N. Amer., 13, 1.

(1936). Amer. J. med. Sci., 192, 445.

SeArS, H. T. N. (1949). Brit. med. J., 2, 1211.

Stevenson, E. M. K., and Brown, T. G. (1943). Glasg. med. J., 140, 139.

TIDY, H. L. (1935). Postgrad. med. J., 11, 346. 